\title{
Acceptability of Vaccination Against Papillomaviruses: A Study On 115 Women at the Matlaboul Fawzayni Hospital in Touba (Senegal)
}

\author{
Omar Gassama ${ }^{1 *}$, Djibril Diallo ${ }^{1}$, Babacar Biaye ${ }^{1}$, Ousmane Thiam² $^{2}$, Chaima En-nidam ${ }^{1}$, Daouda Ndour ${ }^{3}$, Moussa \\ Diallo $^{1}$, Djibril Diallo ${ }^{1}$, Philippe Marc Moreira ${ }^{1}$, Alassane Diouf ${ }^{1}$ and Jean Charles Moreau ${ }^{1}$
}

${ }^{1}$ Aristide Le dantec Teaching Hospital, Gynecologic and Obstetrics clinic Cheikh Anta Diop University, Senegal

${ }^{2}$ Saint Louis Hospital, Gynecologic and Obstetrics Clinic, Gaston Berger University, Senegal

${ }^{3}$ Dalal Jamm Hospital, Pediatrics and Neonatology Clinic, Saint Louis University School of Medicine, Senegal

Submission: November 14, 2019; Published: November 27, 2019

*Corresponding author: Omar Gassama, Aristide Le dantec Teaching Hospital, Gynecologic and Obstetrics clinic Cheikh Anta Diop University, Senegal

Keywords: Women; Health problem; Cancer; Infection; Human papillomavirus; Immunization; Girls; HPV vaccination; knowledge; Gynecology; Socio-epidemiological; Vaccination; Cervical cancer; Anova; Intramuscular injection; Carcinogenic virus; Sensitizing women

Abbreviations: EPI: Expanded Programme on Immunization; HPV: Human Papillomavirus; SPSS: Statistical Package for The Social Sciences

\section{Introduction}

Cervical cancer is a disease which affects young women regardless their ethnic origins and it is a public health problem worldwide. $84 \%$ of new cases throughout the world occur in developing countries [1]. However, this cancer is one of the few types of cancer that can be prevented, so there are two methods of prevention: screening for precancerous lesions and vaccination against the Human Papillomavirus(HPV), which prevents infection and is an effective weapon for its eradication. The World Health Organization (WHO) recommends that girls aged between $9-13$ be vaccinated against HPV. In Senegal, the vaccine against this cancer was introduced in the Expanded Programme on Immunization (EPI) on 31 October 2018 and targets all girls aged 9.

In addition, women are suspicious showing a total mistrust to the HPV vaccination, hence their reluctant attitude to go for it. The vaccination of HPV raises many questions. The objective of our study is to assess women's levels of knowledge of the HPV and their attitudes towards its vaccination at the Mathlaboul Fawzayni Hospital in the city of Touba, Senegal, Diourbel region.

\section{Materials and Methods}

This was a cross-sectional, descriptive and analytical study conducted at the Mathlaboul Fawzayni National Hospital Centre in Touba, from January 07 to February 28, 2019, that is 1 month
21 days. We included in our study all patients who had come for gynecological consultation at the Mathalaboul Fawzayni Hospital

We had obtained the consent of each woman at the beginning of the questionnaire. All women who refused to be surveyed were excluded from this study. An information sheet (appendix) was used as a basis for collecting data from the population. Socioepidemiological factors included age, education level, ethnicity, occupation, marital status, gynecological and obstetrical history, knowledge of human papillomavirus and knowledge of vaccination against human papillomavirus.

\section{Statistical Analysis}

It was carried out by means of a structured individual interview using a questionnaire. The data collection was done with the Epi info software version 7 and the data analysis with the SPSS software (Statistical Package for the social sciences) version 21 . The latter consisted of two parts: descriptive analysis and analytical analysis. In the descriptive part, the qualitative variables were described in terms of number of staff, percentage; the quantitative variables on average with standard deviation, extremes, mode andmedian.

It consisted of a bivariate analysis by comparing the acceptance of HPV vaccine administration with the other variables (previous socio-demographic characteristics...). The 
statistical tests used were the Chi2 test for the percentage comparison, the student test or ANOVA for the mean comparison. The difference was statistically significant when the $p$ value was strictly less than 0.05 . The ORs adjusted with their [95\% CI] were allowed to know the strength of the link.

\section{Result}

A total of 115 women were enlisted. The average age of the women was 31.1 years with the extremes of 15 and 62 years. Women were mainly in the 30-39 age group (51.3\%) as shown in Figure 1. Women were mainly in the 30 -39 age group $(51.3 \%)$ Housewives accounted for more than half of the interviewed women (56.5\%) Women were most often uneducated (55\%) and married (80\%). The average pregnancy rate was 2.5 with extremes of 0 and 12 pregnancies and large multiparous women accounted for $27 \%$.

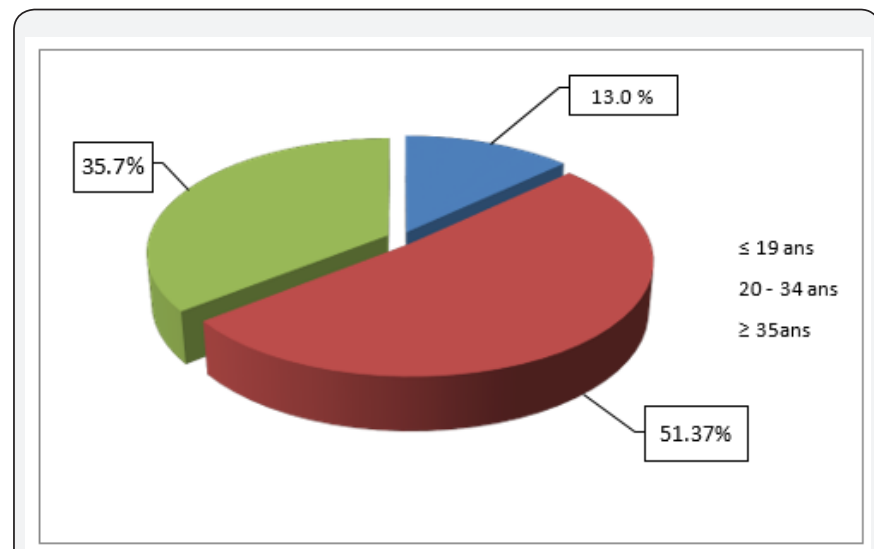

Figure 1: Distribution of women according to age group $(\mathrm{N}=115)$.

The average number of births was 2 with extremes of 0 and 12 births. Primiparous women accounted for $23.5 \%$. The average age at first intercourse was 19 years with extremes of 13 and 31 years. The age at first

pregnancy was 21.3 years with extremes of 15 and 38 years. Skin warts were the main history; in addition, a medical history of cervical and breast cancer was found in 2.6 and $4.3 \%$ of women, respectively, as reported in Table 1.

Table 1: Distribution of women by clinical history $(\mathrm{N}=115)$.

\begin{tabular}{|c|c|c|}
\hline Clinical History & Number & Percentage \\
\hline Skin warts & 32 & 27.8 \\
\hline Genital warts & 19 & 16.5 \\
\hline Breast cancer & 5 & 4.3 \\
\hline Cervical cancer & 3 & 2.6 \\
\hline
\end{tabular}

In our series fifty-six women (48.7\%) knew about HPV. Health workers $(60.7 \%)$ were the main sources of information. Among women who knew about HPV, 94.6\% consider HPV to be sexually transmitted infections and $80.4 \%$ consider it to be responsible for cervical cancer as shown in Figure (2 to 3) In our study only 26 women (21.7\%) knew about HPV vaccines. The media was the main source of information (53.8\%) as reported in Table 2.

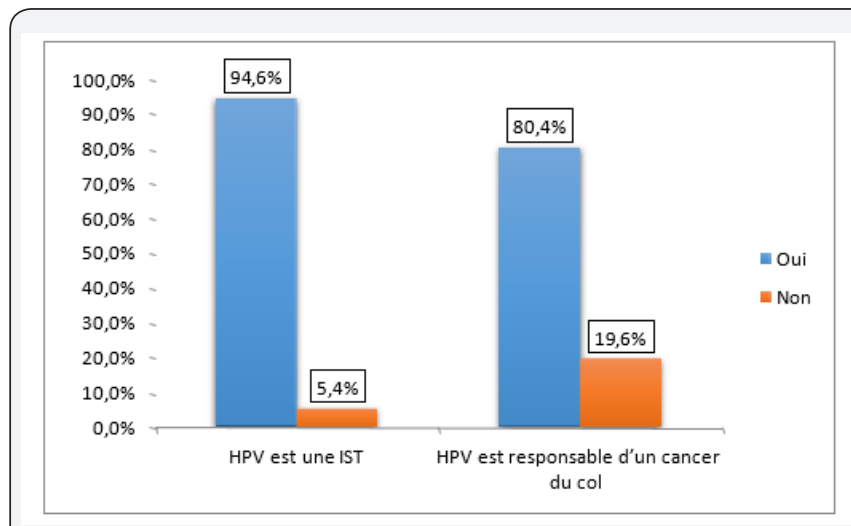

Figure 2: Distribution of women according to their knowledge of the HPV $(\mathrm{N}=56)$.

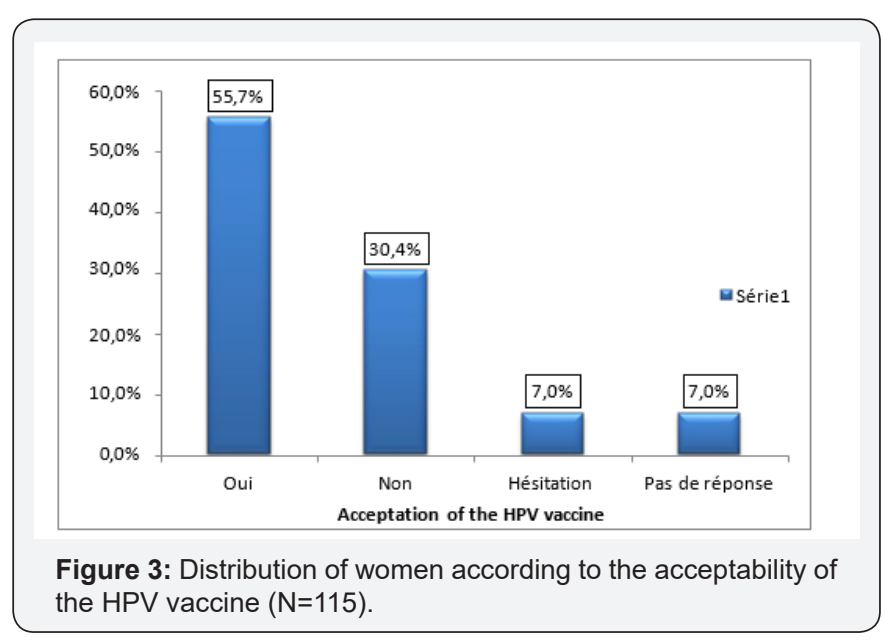

Table 2: Distribution of women according to their sources of information on the HPV vaccine $(\mathrm{N}=26)$.

\begin{tabular}{|c|c|c|}
\hline Sources of Vaccine Information on Hpvs & Number & Percentage \\
\hline TV & 14 & 53.8 \\
\hline Health personal & 11 & 42.3 \\
\hline Family & 5 & 19.2 \\
\hline Radio & 4 & 15.4 \\
\hline Neighbourhood & 2 & 7.7 \\
\hline School & 4 & \\
\hline
\end{tabular}

In our study only $15.4 \%$ of women were aware of the types of HPV vaccine. Gardasil was mentioned by $11.5 \%$ and Cervarix by $11.5 \%$.Among women who were aware of the HPV vaccine, only four $(15.4 \%)$ were aware of the side effects. Fever was the main known side effect of women as reported in Table 3. Among women who were aware of the HPV vaccine, only nine (34.6\%) were aware of the routes of administration of the vaccine. All had cited intramuscular injection as the route of administration. In our study sixteen women (13.9\%) knew the targets. Girls under 13 years of age were the main targets mentioned by women as reported in Table 4. 
Table 3: Distribution of women by HPV vaccine side effects $(\mathrm{N}=4)$.

\begin{tabular}{|c|c|c|}
\hline Side Effects of the HPV & Number & Percentage \\
\hline Fever & 4 & 100 \\
\hline Injection site pain & 3 & 75 \\
\hline Headache & 2 & 50 \\
\hline
\end{tabular}

Table 4: Distribution of women according to targets effects $(\mathrm{N}=16)$.

\begin{tabular}{|c|c|c|}
\hline Targets & Number & Percentage \\
\hline Girls under 13 & 14 & 87.5 \\
\hline Girls under 19 & 8 & 50 \\
\hline Women of all ages & 7 & 43.8 \\
\hline Boys & 2 & 12.5 \\
\hline
\end{tabular}

In our study 64 women (55.7\%) were known to accept to take the HPV vaccine. In our study, $87.1 \%$ of women accept vaccination because they believe it protects them against cervical cancer as reported in Table 5. Lack of information (56.9\%) was the main cause of refusal and hesitation to take vaccination as

Table 5: Distribution of women according to the reasons for accepting the HPV vaccine $(\mathrm{N}=64)$.

\begin{tabular}{|c|c|c|}
\hline $\begin{array}{c}\text { Reasons for Accepting the } \\
\text { HPV Vaccine HPV }\end{array}$ & Number & Percentage \\
\hline Prevention from cancer & 57 & 87.1 \\
\hline $\begin{array}{c}\text { Protection against the virus } \\
\text { 4976.6 }\end{array}$ & 49 & 76.6 \\
\hline
\end{tabular}

reported in Table 6. According to socio-demographic characteristics, there were statistically significant differences in the acceptance rate of HPV vaccine administration.

Table 6: Distribution of women according to the reasons for refusing/ hesitating to take the HPV vaccine $(\mathrm{N}=51)$.

\begin{tabular}{|c|c|c|}
\hline $\begin{array}{c}\text { Reasons for Refusing / Hesitating to } \\
\text { Take the HPV Vaccination }\end{array}$ & Number & Percentage \\
\hline Lack of information & 29 & 56.9 \\
\hline Fear of side effects & 21 & 41.2 \\
\hline No answer & 10 & 19.6 \\
\hline Not concerned & 20 & 39.2 \\
\hline Expensive price & 4 & 7.8 \\
\hline Never been vaccinated & 2 & 3.9 \\
\hline
\end{tabular}

For example, women who were professionally active, those who were educated and monogamous were 5.7, 3.7 and 3.6 times more likely to accept the vaccine (Table 7). According to socio-demographic characteristics, there were statistically significant differences between the acceptance of HPV vaccine administration and occupation, education and marital status. Thus, women who were employed, those who were educated and monogamous were respectively 5.7, 3.7 and 3.6 times more likely to accept the administration of the vaccine as reported in Table 7.

Table 7: Distribution of HPV vaccine acceptance according to the socio- demographic characteristics.

\begin{tabular}{|c|c|c|c|c|c|c|c|}
\hline \multirow{3}{*}{$\begin{array}{l}\text { Socio-Demographic } \\
\text { Characteristics }\end{array}$} & \multicolumn{4}{|c|}{ Acceptability of HPV Vaccine Administration } & \multirow{3}{*}{ Total } & \multirow{3}{*}{ P Value } & \multirow{3}{*}{ Ods[Ic At 95\%] } \\
\hline & \multicolumn{2}{|c|}{ Yes } & \multicolumn{2}{|c|}{ No } & & & \\
\hline & $\mathbf{N}$ & $\%$ & $\mathbf{N}$ & $\%$ & & & \\
\hline Age group & & & & & & 0.193 & \\
\hline$\leq 30$ years & 37 & 61.7 & 23 & 38.3 & 60 & & \\
\hline$>30$ years & 27 & 47.1 & 28 & 50.9 & 55 & & \\
\hline Occupation* & & & & & & 0 & \\
\hline Yes & 39 & 60.9 & 25 & 39.1 & 64 & & $5.7[2.5-13.1]$ \\
\hline No & 11 & 21.6 & 40 & 78.4 & 51 & & 1 \\
\hline Ethnic group & & & & & & 0.071 & \\
\hline Wolof & 54 & 60.7 & 35 & 39.3 & 89 & & \\
\hline Others & 10 & 38.5 & 16 & 61.5 & 26 & & \\
\hline Educated* & & & & & & 0.001 & \\
\hline Yes & 39 & 72.2 & 15 & 27.8 & 54 & & $3.7[1.7-8.2]$ \\
\hline No & 25 & 41 & 36 & 59 & 61 & & 2 \\
\hline Matrimonious regime* & & & & & & 0.014 & \\
\hline Monogamous & 41 & 68.3 & 19 & 31.7 & 60 & & $3.6[1.5-8.8]$ \\
\hline Polygamous & 12 & 37.5 & 20 & 62.5 & 32 & & 1 \\
\hline Unmarried & 11 & 47.8 & 12 & 52.2 & 23 & & $1.5[0.5-4.5]$ \\
\hline
\end{tabular}

The distribution of acceptability of the HPV vaccine did not vary according to personal history (Table 8) The distribution of acceptability of the HPV vaccine was almost similar according to family history (Table 9). The distribution of the acceptability of the HPV vaccine varied according to knowledge of HPV. Women who knew about the HPV were 2.7 times more likely to accept the vaccine (Table 10). The distribution of acceptability of the HPV vaccine was higher among women who were aware of the 


\section{Journal of Gynecology and Women's Health}

routes of administration of the vaccine. Indeed, the latter are 7.1 times more likely to accept the vaccine (Table 11).

Table 8: Distribution of HPV vaccine acceptability according to family history.

\begin{tabular}{|c|c|c|c|c|c|c|}
\hline \multirow{3}{*}{ Personal History } & \multicolumn{4}{|c|}{ Acceptability of HPV Vaccine Administration } & \multirow{3}{*}{ Total } & \multirow{3}{*}{ P Value } \\
\hline & \multicolumn{2}{|c|}{ Yes } & \multicolumn{2}{|c|}{ No } & & \\
\hline & $\mathbf{N}$ & $\%$ & $\mathbf{N}$ & $\%$ & & \\
\hline Number of pregnancies & & & & & & 0.705 \\
\hline$<2$ pregnancies & 28 & 58.3 & 20 & 41.7 & 48 & \\
\hline$\geq 2$ pregnancies & 36 & 53.7 & 31 & 46.3 & 67 & \\
\hline Number of deliveries & & & & & & 0.263 \\
\hline$<2$ deliveries & 32 & 61.5 & 20 & 38.5 & 52 & \\
\hline$\geq 2$ deliveries & 32 & 50.8 & 31 & 49.2 & 63 & \\
\hline Number of children & & & & & & 0.195 \\
\hline$<2$ children & 33 & 62.3 & 20 & 37.7 & 53 & \\
\hline$\geq 2$ children & 31 & 50 & 31 & 50 & 62 & \\
\hline $\begin{array}{l}\text { Age at the } 1 \text { st sexual } \\
\text { intercourse }\end{array}$ & & & & & & 0,052 \\
\hline$\leq 18$ years & 24 & 42.9 & 32 & 57.1 & 56 & \\
\hline$<18$ years & 30 & 62.5 & 18 & 37.5 & 48 & \\
\hline Age at the 1 st pregnancy & & & & & & 0,057 \\
\hline$\leq 20$ years & 24 & 45.3 & 29 & 54.7 & 53 & \\
\hline$<20$ years & 26 & 66.7 & 13 & 33.3 & 39 & \\
\hline Cervical cancer history & & & & & & 0,584 \\
\hline Yes & 1 & 33.3 & 2 & 66.7 & 3 & \\
\hline No & 63 & 56.3 & 49 & 43.8 & 112 & \\
\hline Breast cancer history & & & & & & 0.607 \\
\hline Yes & 3 & 60 & 2 & 40 & 5 & \\
\hline No & 61 & 55.5 & 49 & 44.5 & 110 & \\
\hline Genital warts history & & & & & & 0.805 \\
\hline Yes & 10 & 52.6 & 9 & 47.4 & 19 & \\
\hline No & 54 & 56.3 & 42 & 43.8 & 96 & \\
\hline Skin warts history & & & & & & 0.835 \\
\hline Yes & 17 & 53.1 & 15 & 46.9 & 32 & \\
\hline No & 47 & 56.6 & 36 & 43.4 & 83 & \\
\hline Screening history & & & & & & 0.422 \\
\hline
\end{tabular}

Table 9: Distribution of HPV vaccine acceptability according to the knowledge of HPV.

\begin{tabular}{|c|c|c|c|c|c|c|}
\hline \multirow{3}{*}{ Family History } & \multicolumn{4}{|c|}{ Acceptability of HPV Vaccine Administration } & \multirow{3}{*}{ Total } & \multirow{3}{*}{ Total P Value } \\
\hline & \multicolumn{2}{|c|}{ Yes } & \multicolumn{2}{|c|}{ No } & & \\
\hline & $\mathbf{N}$ & $\%$ & $\mathbf{N}$ & $\%$ & & \\
\hline Cervical Cancer & & & & & & 0.329 \\
\hline Yes & 9 & 45 & 11 & 55 & 20 & \\
\hline No & 55 & 57.9 & 40 & 42.1 & 95 & \\
\hline Cervical Cancer & & & & & & 0.968 \\
\hline Yes & 14 & 56 & 11 & 44 & 20 & \\
\hline No & 50 & 55.6 & 40 & 44.4 & 90 & \\
\hline
\end{tabular}


Journal of Gynecology and Women's Health

Table 10: Distribution of HPV vaccine acceptability according to the knowledge of HPV.

\begin{tabular}{|c|c|c|c|c|c|c|c|}
\hline \multirow{3}{*}{$\begin{array}{c}\text { Knowledge of the HPV } \\
\text { vaccine }\end{array}$} & \multicolumn{4}{|c|}{ Acceptability of the HPV vaccine administration } & \multirow{3}{*}{ Total } & \multirow{3}{*}{ Total P value } & \multirow{3}{*}{ Ods[Ic at95\%] } \\
\hline & \multicolumn{2}{|c|}{ Yes } & \multicolumn{2}{|c|}{ No } & & & \\
\hline & $\mathbf{N}$ & $\%$ & $\mathbf{N}$ & $\%$ & & & \\
\hline Knowledge of HPV & & & & & & 0.014 & \\
\hline Yes & 38 & 18 & 32.1 & 34.6 & 56 & & $2.7[1.3-5.7]$ \\
\hline No & 26 & 33 & 42 & 55.9 & 59 & & 1 \\
\hline HPV is a STD & & & & & & 0.946 & \\
\hline Yes & 37 & 17 & 31.5 & 54 & 4 & & \\
\hline No & 2 & 1 & 33.3 & 3 & 111 & & \\
\hline \multicolumn{8}{|l|}{ HPV causes cervical cancer } \\
\hline Yes & 32 & 13 & 28.9 & 45 & & 0.489 & \\
\hline No & 7 & 5 & 41.7 & 12 & & & \\
\hline
\end{tabular}

Table 11: Distribution of HPV vaccine acceptability according to knowledge of HPV vaccine.

\begin{tabular}{|c|c|c|c|c|c|c|c|}
\hline \multirow{3}{*}{ Knowledge of the HPV Vaccine } & \multicolumn{4}{|c|}{ Acceptability of the HPV Vaccine Administration } & \multirow{3}{*}{ Total } & \multirow{3}{*}{ P Value } & \multirow{3}{*}{ Ods[Ic At95\%] } \\
\hline & \multicolumn{2}{|c|}{ Yes } & \multicolumn{2}{|c|}{ No } & & & \\
\hline & $\mathbf{N}$ & $\%$ & $\mathbf{N}$ & $\%$ & & & \\
\hline Knowledge of the vaccine & & & & & & 0.273 & \\
\hline Yes & 17 & 65.4 & 9 & 34.6 & 26 & & \\
\hline No & 47 & 52.8 & 42 & 47.2 & 89 & & \\
\hline Knowledge of the types of vaccines & & & & & & 0.128 & \\
\hline Yes & 4 & 100 & 0 & 0 & 4 & & \\
\hline No & 60 & 54.1 & 51 & 45.9 & 111 & & \\
\hline
\end{tabular}

\section{Discussion}

In our study, the average age of women was $31.1 \%$; the majority were married $(80 \%)$, the uneducated accounted for (55\%) and those with no professional activity (56.5\%). The mean age at first intercourse was 19 years The mean age at first pregnancy was 23.9 years with extremes (14 and 46). The average pregnancy rate was 2.48 and the average parity rate 2.2 . Our data are comparable to those found in the literature [2-4]. During our study, $48.7 \%$ of women knew about HPV. Of these, 94.6\% consider HPV to be an STI and $80.4 \%$ consider it to be responsible for cervical cancer.

This rate is much lower than the study on obstacles to vaccination against human papillomavirus in girls aged 14 to 19 years in France, where 74\% of girls had already heard of HPV and the majority of whom knew that HPV infection is a sexually transmitted infection [5]. This can be explained by the easier access of French women to information on the one hand, and the plurality of medical staffs they encounter during their medical follow-up and the sexual education they receive on the other. Our rate is even lower than in the 2009 study of 508 high school students in the Alpes Maritimes because $63 \%$ of teenage girls had already heard of HPV in addition, the survey took place only two years after the beginning of HPV vaccination in France. During this period, there was an important communication around this vaccination with important advertising spots [6,7]. Regarding the source of information, most of the women interviewed had heard about it through health workers, and in the media (television, radio). The same results were obtained in the study conducted in 2009 among 508 students in France [6,7] and in a survey on the knowledge and factors influencing HPV vaccination conducted in 2015 among young girls in Nancy, France [8]. We noticed that the rate of knowledge of human Papillomavirus as being an STI and responsible for cervical cancer is very high; this can be explained by the fact that the virus is defined through its consequences and its impact on health.

As for vaccination, only 26 women $(21.7 \%)$ knew about the HPV vaccine. The main sources of information -generally poor - being the media $(62.5 \%)$ and the health workers $(60.7 \%)$. Our results are much lower compared to the studies conducted in France [9,5]. This profile seems incoherent, as it is assumed that women who have heard of HPV, also have certainly heard about its vaccine since the information must be provided simultaneously. The fact that physicians have a central place in the information process highlights the important role they play in cervical cancer prevention and since while offering the HPV vaccine to their patients they should explaining generalities about the HPV (transmission, frequency, possible lesions...) so that their patients understand the implications of this potentially carcinogenic virus. 
The acceptability of taking the HPV vaccine was noted in more than half of the women (55.7\%); the main reason was prevention of cervical cancer and concern about the virus and its health consequences. In fact, there is a correlation between the fact of being sensitized about the HPV, the vaccine and its acceptability. Such reasons were also highlighted in Regnier's qualitative study in 2010 [7]. On the contrary in France in 2018 a study revealed that a relatively low knowledge of the disease does not constitute a barrier to acceptance of vaccination [10]. These contradictions can be explained by the fact that vaccination has recently raised increased reluctance in France.

One of the main reasons why women don't accept HPV vaccine is the lack of knowledge of HPV vaccines and the lack of information. These reasons show that a lack of knowledge or misinformation can prevent vaccination. We can then consider that having information on cervical cancer and its prevention methods favors vaccination. This should encourage us to inform as many girls as possible about HPV vaccination. $[6,11]$ Of course, the most credible source of information and the most considered opinion in the final decision about vaccination is that provided by health workers and physicians. It is proved that general practitioners are increasingly recognized as the cornerstone of prevention programs. Many studies have shown that women who are advised by their doctors for vaccination are more likely to follow the recommendations than those who do not receive any advice [10].

In addition, the second barrier to HPV vaccination was related to the vaccine itself, the fear of side effects, and this matches with the literature. Fear of side effects is at the top of the list in most acceptability surveys. In an American study published in 2013, there was even an increase in this concern, with $4.5 \%$ of parents worried about possible side effects in 2008 , compared to $16.4 \%$ in 2010 [12]. Similarly, in a study of parents in France, fear of vaccine side effects was a blocking factor [10]. Yet HPV vaccines are subject to rigorous surveillance that has so far revealed no serious outbreaks. How then can we explain the growing concern despite the observation of minor side effects and strict safety conditions? "Mistrust of vaccines is as old as vaccination," says Pierrefixe, professor of Health History [13].

Understandable that the deliberate introduction of an infectious agent into a healthy person's body to protect them may be a cause for concern. Nevertheless, this concern has taken unprecedented proportions, particularly in France. The role of the media in disseminating information was clearly perceived; it would seem appropriate to use it as a tool for awareness-raising and to counterbalance messages challenging immunization.

\section{Conclusion}

The success of uterine cervix cancer vaccination involves sensitizing women through the media and health providers about the benefits and safety of vaccines.

\section{References}

1. Organisation Mondiale de la Sante (OMS) (2007) Diagnostic et prise en charge deslésions précancéreuses du col de l'utérus. In: La lutte contre le cancer du col del'utérus: Guide des pratiques essentielles. Genève pp. 135-157.

2. Gassama $O$ (2011) Bilan des activités de colposcopie au service de Gynécologie- Obstétrique du CHU Aristide le Dantec. Thèse Méd, Dakar, Senegal, p. 43.

3. Khaoula B (2016) Les lésions de haut grade du col utérin. Thèse Méd. FES, Senegal, pp. 13-49.

4. Lachiri B (2009) Etude prospective sur la place de la colposcopie dans le dépistage deslésions intraépithéliales du col utérin: àpropos de 565 cas à Temara. Thèse Méd, Rabat, Morocco, pp. 43- 53.

5. Shemelova E (2019) Facteurs influençant la prise de décision sur la vaccination contre le HPV [Thèse Psychologie clinique, pathologie]. Grenoble: Communauté Université Grenoble Alpes, France.

6. Ferenczy A (1995) Epidemiology and clinical pathophysiology of condylomata acuminata. Am J Obstet Gynecol 172(4 pt 2): 1331-1339.

7. Einaudi L, Boubli L, Carcopino X (2015) Comment les traitements d'exérèse des CIN sontils réalisés en France? Une enquête nationale. J Gynécol Obstét Biol Reprod 44(5): 403-410.

8. Hatch KD (1995) Clinical appearance and treatment strategies for human papillomavirus: a gynecologic perspective. Am J Obstet Gynecol 172(4): 1340-1344.

9. Khenchouche A (2014) Le cancer du col de l'utérus : coinfection par le papillomavirus humain et par l'Epstein-barr virus [Thèse Biochimie] Sétif: Université Ferhat Abbas, Algeria.

10. Chiah B (2014) Contribution à l'étude du dépistage du cancer du col de l'utérus au niveau de la wilaya de Bechar et la recherche du Papillomavirus humain par la réaction depolymérisation en chaine [Mémoire Master Microbiologie]. Tlemcen: Université Aboubeker Belkaid, Algeria.

11. Beutner KR, Wiley DJ, Douglas JM, Tyring SK, Fife K, et al. (1999) Genital warts and their treatment. Clin Infect Dis 28(Suppl 1): S37-S56.

12. http://www.medecine-et-sante.com/anatomie.html

13. Pierrefixe SV (2015) Pourquoi font-ils peur? Sci Sant 24: 23-33. 
(C) This work is licensed under Creative

Commons Attribution 4.0 License

DOI: 10.19080/JGWH.2019.17.555965

\section{Your next submission with Juniper Publishers will reach you the below assets}

- Quality Editorial service

- Swift Peer Review

- Reprints availability

- E-prints Service

- Manuscript Podcast for convenient understanding

- Global attainment for your research

- Manuscript accessibility in different formats ( Pdf, E-pub, Full Tsext, Audio)

- Unceasing customer service

Track the below URL for one-step submission https://juniperpublishers.com/online-submission.php 